\title{
Effect of thyroid hormones on serum calcium and phosphorous
}

\author{
Anuj Modi ${ }^{1, *}$, Nita Sahi \\ ${ }^{1,2}$ Assistant Professor, Dept. of Biochemistry, Pacific Medical College and Hospital, Udaipur, Rajasthan, India \\ *Corresponding Author: Anuj Modi \\ Email: anujsmodi@gmail.com
}

Received: $22^{\text {nd }}$ June, 2018

Accepted: $1^{\text {st }}$ August, 2018

\begin{abstract}
Introduction: Calcium and phosphorous are the two important minerals whose abnormalities are most ignored in the developing countries. The impact of calcium abnormalities ranges from abdominal pain, muscle spasms, psychiatric disorders to cardiac arrest. Other than the known regulators of calcium and phosphorous, thyroid hormones may affect the levels of calcium and phosphorous. The aim of our study is to estimate serum calcium, phosphorous and thyroid profile and to see the effect of thyroid hormones on serum calcium and phosphorous.

Materials and Methods: 40 hyperthyroid and 40 hypothyroid patients were taken as cases. 40 healthy individuals were taken as controls. Thyroid profile, serum calcium and phosphorous were estimated in cases and controls. Serum calcium and phosphorous levels were compared with thyroid hormones among cases and controls. Correlation of thyroid hormones with serum calcium and phosphorous were done.

Result: The mean serum calcium and phosphorous levels in hyperthyroid patients are $12.7 \pm 0.89 \mathrm{mg} / \mathrm{dl}$ and $5.1 \pm 0.68 \mathrm{mg} / \mathrm{dl}$ respectively which are increased ( $\mathrm{p}$ value $<0.05$ ) compared to controls. The mean serum calcium and phosphorous levels are 6.9 $\pm 0.93 \mathrm{mg} / \mathrm{dl}$ and $2.3 \pm 1.1 \mathrm{mg} / \mathrm{dl}$ respectively in hypothyroid patients which are decreased (p value <0.05) compare to controls. Strong correlations of all thyroid hormones with serum calcium and phosphorous in hyperthyroidism and hypothyroidism is seen (p value <0.05).

Conclusion: Hyperthyroidism and hypothyroidism may lead to hypercalcemia and hypocalcemia respectively, which are the cause of may disorders and disabilities. The concentration of serum calcium and phosphorous should be checked regularly in those patients.
\end{abstract}

Keywords: Hyperthyroidism, Hypothyroidism, Serum calcium, Serum phosphorous.

\section{Introduction}

Calcium and phosphorous are very important minerals in our body, which are regulated by various mechanisms in our body. Alteration in the homeostasis of these minerals will lead to hazardous effects in the body. The adverse effects of hypercalcemia are anorexia, confusion, psychosis, renal stones etc. The symptoms of hypocalcemia are muscle cramps, paresthesia, tetany, seizures etc. ${ }^{1}$

Other than the usual regulators of calcium and phosphorous like vitamin $\mathrm{D}$, calcitonin and parathyroid hormones, it is said that thyroid hormones also play a role in the regulation of calcium and phosphorous in our body. ${ }^{1,2}$

Thyroid hormones which include T3, T4 and TSH play a major role in the cellular development, thermogenic maintenance and mineral and metabolic processes in our body. ${ }^{3}$ On one hand hyperthyroidism is responsible for decreased bone mineral density, increased osteoporotic fractures and increase serum calcium and phosphorous levels, on the other hand hypothyroidism is known to decrease serum calcium and phosphorous levels. ${ }^{4-7}$

In hyperthyroidism there is accelerated bone turn over and poor mobilization of calcium that leads to increase serum calcium and phosphorous concentration. While in hypothyroidism opposite effect takes place. ${ }^{2,4}$
Previous studies done on calcium and phosphorous in thyroid disorders had conflicting results. Some studies had shown normal levels of calcium and phosphorous in thyroid disorders, while others had shown altered levels. ${ }^{8}$

The aim of our study was to determine the serum calcium and phosphorous levels in the hyperthyroid and hypothyroid patients and to compare them with the healthy controls to determine the effect of thyroid hormones on serum calcium and phosphorous.

\section{Materials and Methods}

The study was conducted in the Department of Biochemistry, Pacific Medical College and Hospital, Udaipur between August 2016 to March 2018. Institutional ethics committee clearance had been taken before starting the study. 40 patients with hypothyroidism and 40 patients with hyperthyroidism were enrolled in the study as cases along with 40 healthy individuals were taken as control group. Clinical and laboratory diagnosis had been done to determine the cases and controls.

Individuals with any hepatic, renal and cardiac disease, chronic infection, any medication to treat thyroid disorders or affect thyroid hormones and calcium and phosphorous concentration, alcoholism, on mineral supplements were excluded from the study. 
After taking informed consent, $2 \mathrm{ml}$ of venous blood was withdrawn from the study group in the plain vacutainer. Blood was allowed to clot, and centrifuge was done to separate serum. Serum thus separated was stored at $4-8^{\circ} \mathrm{c}$ temperature till the analysis was done. Estimation of serum T3, T4 and TSH were done by fully automated analyzer cobas e411 and serum calcium and phosphorous were analyzed by fully automated analyzer cobas $\mathrm{c} 311$.

\section{Statistical Analysis}

The results are expressed as mean $\pm \mathrm{SD}$. Unpaired student ' $\mathrm{t}$ ' test was applied to compare the different parameters between cases and controls. 'p' value $<0.05$ was considered as statistically significant. Pearson's correlation coefficient was applied to see the correlation between thyroid profile and serum calcium and phosphorous. 'p' value $<0.05$ was considered as statistically significant in Pearson's correlation coefficient.

\section{Result}

As shown in Table 1, there is no significant difference in the gender and age between cases and controls. Also, there is clear increase in the Serum T3, $\mathrm{T} 4$ and decrease in the TSH levels. There is significant difference in the serum calcium and phosphorous between hyperthyroidism and control group with the $\mathrm{p}$ value $<0.05$. The concentration of both serum calcium and phosphorous are increased in the hyperthyroid patients compare to control group.

As shown in Table 2, there is no difference in gender and age between cases and controls. Also, there is clear decrease in the concentration of T3, T4 and increase in TSH levels. There is decrease concentration of serum calcium and phosphorous in the hypothyroid patients compared to normal control group. The difference is statistically significant with $\mathrm{p}$ value < 0.05 .

As shown in Table 3 there is significant positive correlation of serum T3 with serum calcium in both hyperthyroid and hypothyroid patient. The $r$ value is +0.85 and +0.82 respectively ( $\mathrm{p}$ value $<0.05$ in both). There is also strong positive correlation of serum T4 with serum calcium in hyperthyroid and hypothyroid patient $(r$ value +0.79 and +0.88 respectively and $p$ value $<0.05$ in both). There strong positive correlation between serum T3 and T4 with serum phosphorous in hyperthyroid and hypothyroid patients ( $\mathrm{r}$ value +0.74 , $+0.76,+0.68$ and +0.65 respectively and $p$ value $<0.05$ in all). There is strong negative correlation between TSH and serum calcium levels in both hyperthyroid and hypothyroid patients ( $\mathrm{r}$ value -0.73 and -0.69 respectively and $\mathrm{p}$ value $<0.05$ in both). There is also strong negative correlation between TSH and serum phosphorous levels in hyperthyroid and hypothyroid patients ( $\mathrm{r}$ value -0.62 and -0.69 respectively and $\mathrm{p}$ value $<0.05$ in both).

Table 1: Shows the comparison of demographic details, thyroid profile, serum calcium and phosphorous levels in hyperthyroid cases with normal healthy controls

\begin{tabular}{|l|c|c|c|}
\hline & Hyperthyroidism & Control & \\
\hline Gender $(F e m a l e / m a l e)$ & $30 / 10$ & $28 / 12$ & Not Significant \\
\hline Age $($ years $)$ & $35.3 \pm 5.6$ & $34.7 \pm 6.1$ & No Significant \\
\hline Serum T3 $(\mathrm{ng} / \mathrm{ml})$ & $3.1 \pm 0.15$ & $1.4 \pm 0.18$ & $\mathrm{p}$ value $<0.05$ \\
\hline Serum T4 $(\mu \mathrm{g} / \mathrm{dl})$ & $15.3 \pm 1.1$ & $9.7 \pm 2.4$ & $\mathrm{p}$ value $<0.05$ \\
\hline Serum TSH $(\mu \mathrm{IU} / \mathrm{ml})$ & $0.09 \pm 0.03$ & $2.67 \pm 0.45$ & $\mathrm{p}$ value $<0.05$ \\
\hline Serum Calcium $(\mathrm{mg} / \mathrm{dl})$ & $12.7 \pm 0.89$ & $9.5 \pm 1.2$ & $\mathrm{p}$ value $<0.05$ \\
\hline Serum Phosphorous $(\mathrm{mg} / \mathrm{dl})$ & $5.1 \pm 0.68$ & $3.6 \pm 0.79$ & p value $<0.05$ \\
\hline
\end{tabular}

Table 2. Shows the comparison of demographic details, thyroid profile. Serum calcium and phosphorous levels in hypothyroid cases with normal healthy controls

\begin{tabular}{|l|c|c|c|}
\hline & Hypothyroidism & Control & \\
\hline Gender $($ Female/Male) & $29 / 11$ & $28 / 12$ & Not Significant \\
\hline Age $($ Years $)$ & $33.6 \pm 4.7$ & $34.7 \pm 6.1$ & Not Significant \\
\hline Serum T3(ng/ml) & $0.4 \pm 0.02$ & $1.4 \pm 0.18$ & $\mathrm{p}$ value $<0.05$ \\
\hline Serum T4 $(\mu \mathrm{g} / \mathrm{dl})$ & $2.7 \pm 0.59$ & $9.7 \pm 2.4$ & $\mathrm{p}$ value $<0.05$ \\
\hline Serum TSH $(\mu \mathrm{IU} / \mathrm{ml})$ & $6.1 \pm 1.6$ & $2.67 \pm 0.45$ & $\mathrm{p}$ value $<0.05$ \\
\hline Serum Calcium $(\mathrm{mg} / \mathrm{dl})$ & $6.9 \pm 0.93$ & $9.5 \pm 1.2$ & $\mathrm{p}$ value $<0.05$ \\
\hline Serum Phosphorous $(\mathrm{mg} / \mathrm{dl})$ & $2.3 \pm 1.1$ & $3.6 \pm 0.79$ & $\mathrm{p}$ value $<0.05$ \\
\hline
\end{tabular}


Table 3: Shows the correlation of thyroid profile with serum calcium and phosphorous in hyperthyroidism and hypothyroidism

\begin{tabular}{|l|c|c|}
\hline \multicolumn{1}{|c|}{ Correlation between } & Hyperthyroidism & Hypothyroidism \\
\hline Serum T3 and Serum Calcium & $\begin{array}{c}\text { r value }=+0.85 \\
\text { p value }<0.05\end{array}$ & $\begin{array}{c}\text { r value }=+0.82 \\
\text { p value }<0.05\end{array}$ \\
\hline Serum T4 and Serum Calcium & $\begin{array}{c}\text { r value }=+0.79 \\
\text { p value }<0.05\end{array}$ & $\begin{array}{c}\text { r value }=+0.88 \\
\text { p value }<0.05\end{array}$ \\
\hline Serum TSH and Serum & r value $=-0.73$ & r value $=-0.69$ \\
Calcium & p value $<0.05$ & p value $<0.05$ \\
\hline Serum T3 and Serum & r value $=+0.74$ & r value $=+0.76$ \\
Phosphorous & p value $<0.05$ & p value $<0.05$ \\
\hline Serum T4 and Serum & r value $=+0.68$ & r value $=+0.65$ \\
Phosphorous & p value $<0.05$ & p value $<0.05$ \\
\hline Serum TSH and Serum & r value $=-0.62$ & r value $=-0.69$ \\
Phosphorous & p value $<0.05$ & p value $<0.05$ \\
\hline
\end{tabular}

\section{Discussion}

The thyroid gland secretes two most important hormones i.e. T3 and T4. They influence almost all metabolisms like carbohydrate, lipid and protein metabolism. They also maintain water and electrolyte homeostasis. Recently thyroid hormones are having greater attention because of their effects on mineral metabolism. ${ }^{13}$

In our study we have divided cases into two groups. Based on clinical and laboratory diagnosis, one group is having hyperthyroidism, and another group is having hypothyroidism. The concentration of serum calcium and phosphorous have been compared between these groups and healthy controls.

As per our study, there is significant increase in the concentration of serum calcium and phosphorous between hyperthyroid patient and healthy controls. Our results are consistent with the research done by Indrajit Nath et al., ${ }^{3}$ Shivleela MB et al., ${ }^{9}$ Abdelgayoum A., ${ }^{5}$ Mosekilde et al. ${ }^{14}$ and Manicort et al. ${ }^{15}$

As per our study, there is significant decrease in the concentration of serum calcium and phosphorous between hypothyroid patients and control group. Similar results have been found in the studies done by D. Sridevi et al., ${ }^{16}$ Malamos et al. ${ }^{17}$ and Gamage et al. ${ }^{18}$

As per our study there is strong positive correlation of Serum T3 and T4 with Serum calcium ( $p$ value $<0.05$ ) and strong negative correlation of Serum TSH with Serum Calcium ( $p$ value $<0.05)$ in hyperthyroidism which suggests that Serum calcium level will increase as there is increase in the severity of hyperthyroidism. There is also strong positive correlation of Serum T3 and T4 with Serum calcium and strong negative correlation of Serum TSH with Serum calcium ( $\mathrm{p}$ value $<0.05$ ) in hypothyroidism which also suggests that as the severity of hypothyroidism increases Serum Calcium concentration decreases. Same effects are also seen in the serum Phosphorous levels. These results are consistent with the research by Indrajit Nath et al., ${ }^{3}$ Abdelgayoum A., ${ }^{5}$ Mosekilde et al., ${ }^{14}$ Malamos et al. ${ }^{17}$ Gamage et al. ${ }^{18}$
The increase in the serum calcium and phosphorous levels in the hyperthyroid patient is because of effect of thyroid hormones on osteoblast to stimulate osteoclastic bone resorption via nuclear receptors, which increases bone turnover. PTH suppression as well as direct effect of thyroid hormone on tissue phosphate metabolism and renal phosphate will lead to the changes occurring in the phosphate concentration. The molecular mechanism behind the effect of thyroid hormones on serum calcium and phosphorous is multifactorial. The hyperthyroid state increases sensitivity of beta adrenergic receptors to catecholamines. Thyroid hormones especially T3 increase sensitivity of IL- 6 to bones, which increases osteoclastic differentiation by increasing the expression of the receptor of nuclear factor $\kappa \mathrm{B}$ ligand. These all leads to increase concentration of serum calcium and phosphorous. While in hypothyroidism opposite effect will occur. ${ }^{3,19,20,21}$

In hypothyroid patients, there may be increase production of calcitonin with decrease availability of thyroxine inside the cell which will lead to increase tubular excretion of calcium and decrease extracellular calcium release, ultimately will lead to decrease concentration of serum calcium. ${ }^{16}$

\section{Conclusion}

Hypercalcemia and hypocalcemia are two abnormalities which are very much neglected in India. They can lead to various abnormalities and disabilities. In our study we found that serum calcium and phosphorous are affected by the thyroid hormones. Whenever there are any thyroid hormone disturbances, alterations in the levels of serum calcium and phosphorous should be looked for to prevent any abnormalities from occurring. 


\section{References}

1. DM Vasudevan, Sreekumari S and Kannan

Vaidyanathan, mineral metabolism and abnormalities. In: DM Vasudevan, Sreekumari S and Kannan

Vaidyanathan, Textbook of biochemistry for medical students, $8^{\text {th }}$ edition; Jaypee Brothers Medical Publisher (P) Ltd, 2016;491-497.

2. Kavitha MM, Chandrashekharyya SH. Alteration in levels of serum calcium, phosphorous and magnesium in patients of hypothyroidism. International journal of biological and medical research. 2014;5(4):4594-4596.

3. Indrajit Nath, Swati Bhattacharyya and Mita Saha. Study of electrolyte status in patient with thyroid dysfunction attending a tertiary care hospital of North Bengal. International Journal of Biomedical Research. 2018;09(02):72-75.

4. Arvind Bharti, Shailaza Shrestha. assessment of serum minerals and electrolytes in thyroid patients.

International journal of advances in scientific research. 2015;1(06): 259-263.

5. Abdelgayoum A. dyslipidemia and serum mineral profiles in patients with thyroid disorders. Saudi medical journal. 2014;35(12):1469-1476.

6. Mukesh G Gohel, Aashka M Shah. a study of serum calcium, magnesium and phosphorous in hypothyroidism patients. International journal of Medical and Health sciences. 2014;3(4):308-312.

7. Gagandeep Kaur Sidhu, Rahima Malek. assessment of variations in serum Phosphorous, Calcium, sodium and potassium levels in hypothyroid patients. Int J Int Med Res. 2016;3(3):26-29.

8. AlaEldin S. Ashmaik, Haala M. Gabra. Assessment of serum levels of calium and phosphorous in Sudanese patients with hypothyroidism. Asian journal of Biomedical and Pharmaceutical sciences. 2013;03(25):21-26.

9. Shivaleela MB, Poornima RT and Jayaprakash Murthy DS. Serum calcium and phosphorus levels in thyroid dysfunction. Indian Journal of Fundamental and Applied Life Sciences. 2012;2(2):179-183.

10. Suneel B., D.R. Nagendra, R.R. Aparna, D. Balakrishna, J.N. Naidu. Mineral Status in Thyroid Disorder (Hypo \& Hyper). International Journal of Applied Biology and Pharmaceutical Technology. 2011;2(4):423-429.

11. Beqic KS, Wagner B, Raber W. Serum calcium in thyroid disease. Wiener Klinische Wochenschrift. 2001;113(1-2): 65-68.
12. Sabuncu T, Aksoy N, Arikan E. Early changes in parameters of bone and mineral metabolism during therapy for hyperthyroidism and hypothyroidism. Endocrine Research. 2001;27(1-2): 201-213.

13. Susanna TY, Sagayaraj A. A correlative study of thyroid profile and mineral status in patients with hypothyroidism - a hospital base case control study. Asian journal of Pharmaceutical and Clinical Research. 2016;9(3):292294.

14. Mosekilde L, Melsen F, Bagger JP, Myhre JO, Schwartz $\mathrm{SN}$. Bone changes in hyperthyroidism: interrelationship between morphometry, thyroid function and calciumphosphorous metabolism. Acta Endocrinologica. 1977;85(3):515-525.

15. Manicourt D, Demeester M N, Brauman H, Corvilain J. Disturbed mineral metabolism in hyperthyroidism: good correlation with triiodthyronine. Clinical Endocrinology. 1979;10(4):407-412.

16. Sridevi D, Amrut A Dambal. A study of Serum magnesium, Calcium and Phosphorous in hypothyroidism. International Journal of Clinical Biochemistry and Research. 2016;3(2):236-239.

17. Malamos B, Sfikakis P and Pandos P. The renal handling of phosphate in thyroid disease. Journal of Endocrinology. 1969;45(2):269-273.

18. Gammage MD and Logan SD. Effects of thyroid dysfunction on serum calcium in the rat. Clinical Science. 1986;71(3):271-276.

19. Auwerx $\mathrm{J}$ and Bouillon R. Mineral and bone metabolism in thyroid disease: A Review. Quarterly Journal of Medicine. 1986;60(2):737-752.

20. Fathimabeebi PK, Noor Bader Al Busaidi and Mohamed Al Lamki. Hypercalcemia, an uncommon presentation of hyperthyroidism. Int Arch Endocrinol Clin Res. 2015;1:003.

21. Ke Chen, Yanhong Xie, Liling Zhao and Zhaohui Mo. Hyperthyroidism-associated hypercalcemic crisis. Medicine. 2017;96:4.

How to cite this article: Modi A, Sahi N. Effect of thyroid hormones on serum calcium and phosphorous. Int $\mathbf{J}$ Clin Biochem Res. 2018;5(4):570-573. 